\title{
Can the Term Spread Predict Output Growth and Recessions? A Survey of the Literature
}

\author{
David C. Wheelock and Mark E. Wohar
}

\begin{abstract}
This article surveys recent research on the usefulness of the term spread (i.e., the difference between the yields on long-term and short-term Treasury securities) for predicting changes in economic activity. Most studies use linear regression techniques to forecast changes in output or dichotomous choice models to forecast recessions. Others use time-varying parameter models, such as Markov-switching models and smooth transition models, to account for structural changes or other nonlinearities. Many studies find that the term spread predicts output growth and recessions up to one year in advance, but several also find its usefulness varies across countries and over time. In particular, many studies find that the ability of the term spread to forecast output growth has diminished in recent years, although it remains a reliable predictor of recessions.
\end{abstract} (JEL C53, E37, E43)

Federal Reserve Bank of St. Louis Review, September/October 2009, 91(5, Part 1), pp. 419-40.

nformation about a country's future economic activity is important to consumers, investors, and policymakers. Since Kessel (1965) first discussed how the term structure of interest rates varies with the business cycle, many studies have examined whether the term structure is useful for predicting various measures of economic activity. The term spread (the difference between the yields on long-term and short-term Treasury securities) has been found useful for forecasting such variables as output growth, inflation, industrial production, consumption, and recessions, and the ability of the spread to predict economic activity has become something of a "stylized fact" among macroeconomists.

This article surveys recent research investigating the ability of the term spread to forecast output growth and recessions. ${ }^{1}$ The article briefly discusses theoretical explanations for why the spread might predict future economic activity and then surveys empirical studies that investigate how well the spread predicts output growth and recessions. The survey describes the data and methods used in various studies to investigate the predictive power of the term spread, as well as key findings. In general, the literature has not reached a consensus about how well the term spread predicts output growth. Although many studies do find that the spread predicts output growth at one-year horizons, studies also find considerable variation across countries and over time. In particular, many studies find that the ability of the spread to forecast output growth has declined since the mid-1980s. The empirical literature provides more consistent evidence that

1 Surveys of the older literature include Berk (1998), Dotsey (1998), Estrella and Hardouvelis (1991), Plosser and Rouwenhorst (1994), and Stock and Watson (2003). Stock and Watson (2003) also survey research on the usefulness of asset prices for forecasting inflation.

David C. Wheelock is a vice president and economist at the Federal Reserve Bank of St. Louis. Mark E. Wohar is a professor of economics at the University of Nebraska at Omaha. The authors thank Michael Dueker, Massimo Guidolin, and Dan Thornton for comments on a previous draft of this article. Craig P. Aubuchon provided research assistance.

(C) 2009, The Federal Reserve Bank of St. Louis. The views expressed in this article are those of the author(s) and do not necessarily reflect the views of the Federal Reserve System, the Board of Governors, or the regional Federal Reserve Banks. Articles may be reprinted, reproduced, published, distributed, displayed, and transmitted in their entirety if copyright notice, author name(s), and full citation are included. Abstracts, synopses, and other derivative works may be made only with prior written permission of the Federal Reserve Bank of St. Louis. 


\section{Figure 1}

\section{U.S. Term Spread and Recessions}

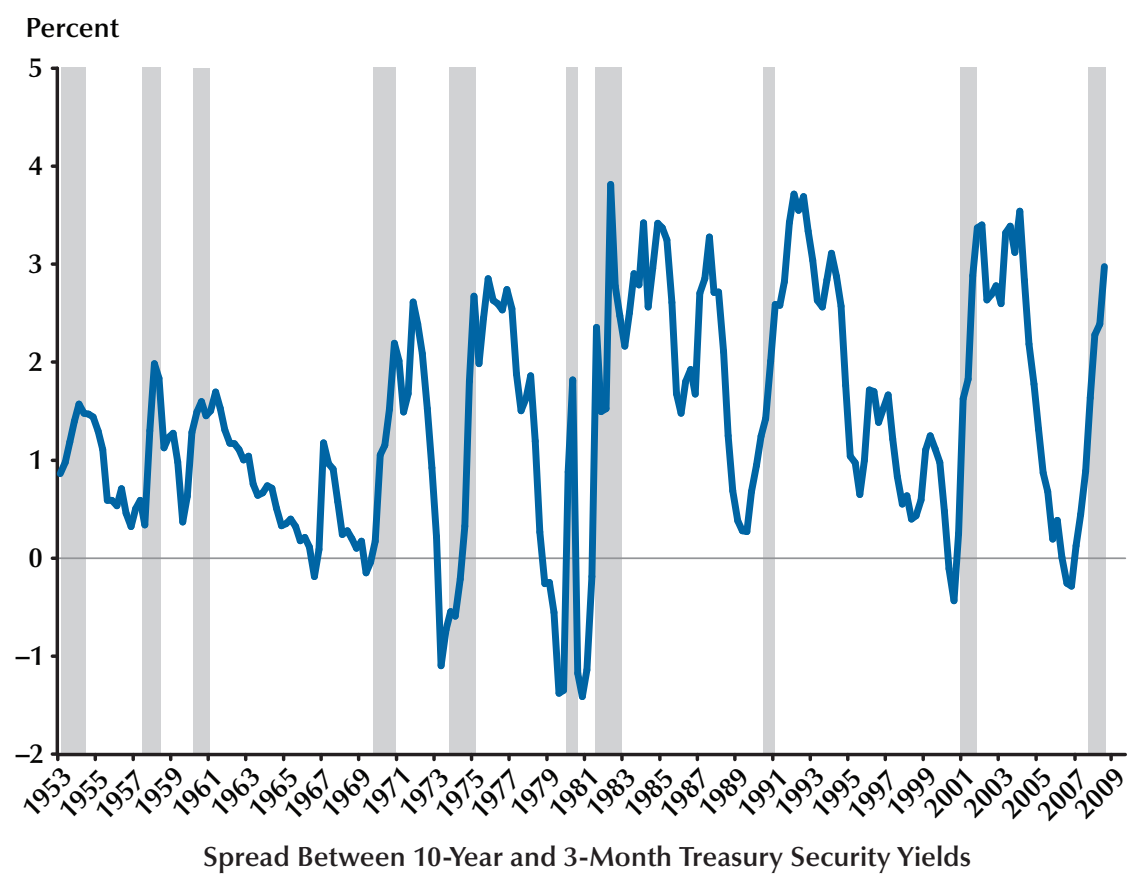

NOTE: The term spread is calculated as the difference between the yields on 10-year and 3-month Treasury securities. The shaded areas denote recessions as determined by the National Bureau of Economic Research.

the term spread is useful for predicting recessions. Furthermore, the relationship appears robust to the inclusion of other variables and nonlinearities in the forecasting model.

\section{A LOOK AT THE DATA}

Yields on long-term securities typically exceed those on otherwise comparable short-term securities, reflecting the preference of most investors to hold instruments with shorter maturities. Hence, the yield curve, which is a plot of the yields on otherwise comparable securities of different maturities, is typically upward sloping. Analysts have long noted, however, that most recessions are preceded by a sharp decline in the slope of the yield curve and frequently by an inversion of the yield curve (i.e., by short-term yields rising above those on long-term securities).
Figure 1 shows the difference between the yields on 10-year and 3-month U.S. Treasury securities for 1953-2008. The shaded regions indicate recession periods as defined by the National Bureau of Economic Research. ${ }^{2}$ As Figure 1 shows, every U.S. recession since 1953 was preceded by a large decline in the yield on 10-year Treasury securities relative to the yield on 3-month Treasury securities, and several recessions were preceded by an inversion of the yield curve. Moreover, the only occasion when the 3-month Treasury security yield exceeded the (constant-maturity) 10-year Treasury yield without a subsequent recession was in December 1966.

Similar data for Germany and the United Kingdom are shown in Figures 2 and 3, respec-

\footnotetext{
2 National Bureau of Economic Research, "Information on Recessions and Recoveries, the NBER Business Cycle Dating Committee, and Related Topics"; www.nber.org/cycles/main.html.
} 


\section{Figure 2}

\section{German Term Spread and Recessions}

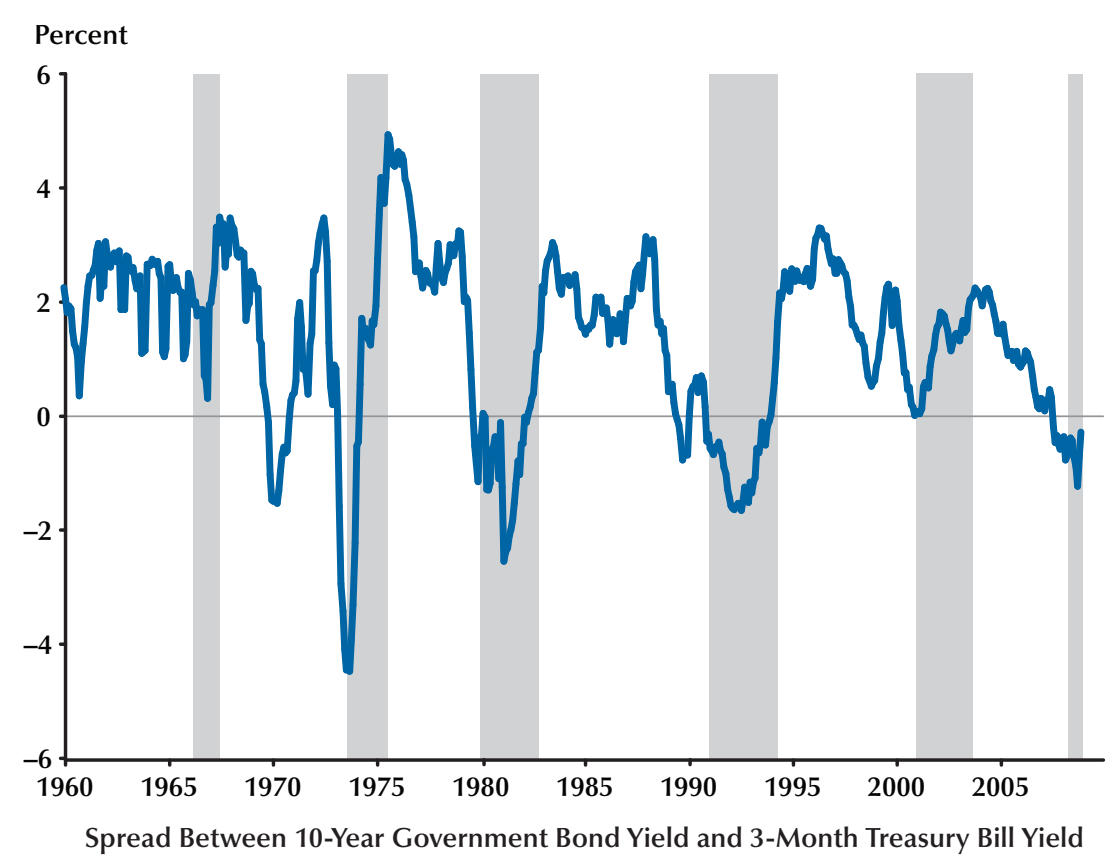

NOTE: The term spread is calculated as the difference between the yields on 10-year and 3-month Treasury securities. The shaded areas denote recessions as determined by the Economic Cycle Research Institute.

tively. Germany experienced recessions beginning in 1966, 1974, 1980, 1991, 2000, and 2008. All but the 1966 recession were preceded by a sharp decline in long-term Treasury security yields relative to short-term yields that resulted in a flat or inverted yield curve. The only inversion that was not followed by a recession occurred in 1970.

The United Kingdom experienced recessions beginning in 1974, 1979, 1990, and 2008. All were preceded by or coincided with a yield curve inversion. However, large inversions in 1985 and 1997-98 were not followed by recessions. ${ }^{3}$

Table 1 summarizes additional information about the association between the term spread and economic activity. The table presents correlations between the term spread (measured as a

3 Recession dates for Germany and the United Kingdom are from the Economic Cycle Research Institute, as reported by Haver Analytics. Interest rate data for Germany and the United Kingdom are from Global Insight. quarterly average of monthly observations) and the year-over-year percentage change in real gross domestic product (GDP) for the United States, Germany, and the United Kingdom. The table presents the contemporaneous correlation between the two variables, as well as correlations at various leads and lags of the term spread relative to GDP growth. The top panel of the table reports correlations between GDP growth in one quarter and the term spread in the same quarter $(t)$ and in six preceding quarters ( $t-1$ and so on). The bottom panel reports the correlations between GDP growth in one quarter and the term spread in the same quarter and in the six subsequent quarters $(t+1$ and so on).

The contemporaneous correlation between GDP growth and the term spread is not statistically different from zero for any of the three countries (column 1 in Table 1). By contrast, the correlations between GDP growth and the term spread lagged 
Figure 3

\section{U.K. Term Spread and Recessions}

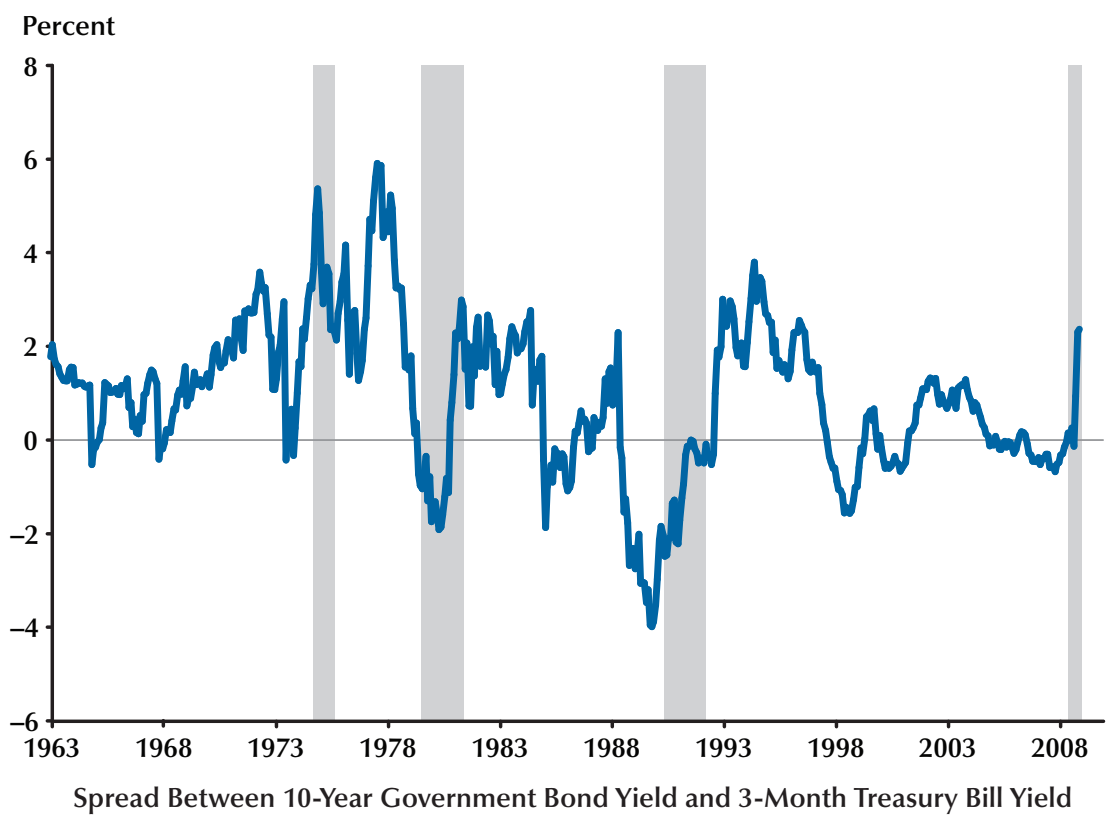

NOTE: The term spread is calculated as the difference between the yields on 10-year and 3-month Treasury securities. The shaded areas denote recessions as determined by the Economic Cycle Research Institute.

from one to six quarters are uniformly positive and statistically significant (indicated by $p$-values of 0.10 or less) for all three countries, except for the correlation between U.S. GDP growth and the term spread lagged by one quarter. Thus, the correlations indicate that, in general, the higher the yield on 10-year Treasury securities relative to the yield on 3-month Treasury securities-that is, the more steeply sloped the yield curve-the higher the rate of future GDP growth. Similarly, the less steeply sloped the yield curve, the lower the subsequent rate of GDP growth.

The correlations between current GDP growth and future term spreads shown in the lower panel are negative and for the most part statistically significant for all three countries. Thus, a higher GDP growth rate in one quarter is associated with a less steeply sloped yield curve in subsequent quarters.

As discussed in more detail in the following section, the pattern of positive correlation between current GDP growth and lagged term spreads and negative correlation between current GDP growth and future term spreads is consistent with more than one explanation of the relationship between the yield curve and output growth. Further, although the unconditional correlation between output growth and the term spread is high, the correlation might reflect the influence of some other variable, in which case the term spread would not forecast output growth if that other influence is included in the forecasting model. After discussing why the term spread might forecast economic activity in the next section, we review empirical research on the usefulness of the term spread for forecasting output growth and recessions in subsequent sections.

\section{WHY MIGHT THE TERM SPREAD FORECAST ECONOMIC ACTIVITY?}

Although many empirical studies find that the term spread predicts future economic activity, 


\section{Table 1}

\section{Correlation of GDP Growth and Lagged and Future Term Spreads by Country}

\begin{tabular}{|c|c|c|c|c|c|c|c|}
\hline & \multicolumn{7}{|c|}{ Lagged term spread } \\
\hline & \multicolumn{7}{|c|}{ Term } \\
\hline & $t$ & $(t-1)$ & $(t-2)$ & $(t-3)$ & $(t-4)$ & $(t-5)$ & $(t-6)$ \\
\hline United States & $\begin{array}{c}-0.0449 \\
(0.5047)\end{array}$ & $\begin{array}{c}0.0999 \\
(0.1379)\end{array}$ & $\begin{array}{c}0.2557 \\
(0.0001)\end{array}$ & $\begin{array}{c}0.3605 \\
(0.0001)\end{array}$ & $\begin{array}{c}0.4141 \\
(0.0001)\end{array}$ & $\begin{array}{c}0.3957 \\
(0.0001)\end{array}$ & $\begin{array}{c}0.3196 \\
(0.0001)\end{array}$ \\
\hline Germany & $\begin{array}{c}-0.0003 \\
(0.9970)\end{array}$ & $\begin{array}{c}0.1641 \\
(0.0455)\end{array}$ & $\begin{array}{c}0.2991 \\
(0.0002)\end{array}$ & $\begin{array}{c}0.3689 \\
(0.0001)\end{array}$ & $\begin{array}{c}0.3845 \\
(0.0001)\end{array}$ & $\begin{array}{c}0.3649 \\
(0.0001)\end{array}$ & $\begin{array}{c}0.3421 \\
(0.0001)\end{array}$ \\
\hline United Kingdom & $\begin{array}{c}0.0723 \\
(0.3319)\end{array}$ & $\begin{array}{c}0.1816 \\
(0.0144)\end{array}$ & $\begin{array}{c}0.2486 \\
(0.0008)\end{array}$ & $\begin{array}{c}0.3025 \\
(0.0001)\end{array}$ & $\begin{array}{c}0.3379 \\
(0.0001)\end{array}$ & $\begin{array}{c}0.3166 \\
(0.0001)\end{array}$ & $\begin{array}{c}0.2607 \\
(0.0005)\end{array}$ \\
\hline
\end{tabular}

\begin{tabular}{lccccccc} 
& \multicolumn{7}{c}{ Tuture term spread } \\
\cline { 2 - 7 } & \multicolumn{7}{c}{ Term } \\
\cline { 2 - 7 } & $t$ & $(t+1)$ & $(t+2)$ & $(t+3)$ & $(t+4)$ & $(t+5)$ & $(t+6)$ \\
\hline United States & -0.0449 & -0.1428 & -0.2374 & -0.2994 & -0.3372 & -0.3538 & -0.3421 \\
& $(0.5047)$ & $(0.0335)$ & $(0.0004)$ & $(0.0001)$ & $(0.0001)$ & $(0.0001)$ & $(0.0001)$ \\
Germany & -0.0003 & -0.1722 & -0.3414 & -0.4424 & -0.4548 & -0.4545 & -0.4110 \\
United Kingdom & $(0.9970)$ & $(0.0357)$ & $(0.0001)$ & $(0.0001)$ & $(0.0001)$ & $(0.0001)$ & $(0.0001)$ \\
& 0.0723 & -0.0364 & -0.1366 & -0.2116 & -0.2306 & -0.2204 & -0.2261 \\
& $(0.3319)$ & $(0.6244)$ & $(0.0652)$ & $(0.0040)$ & $(0.0017)$ & $(0.0001)$ & $(0.0021)$
\end{tabular}

NOTE: U.S. data are for 1953:Q1-2008:Q4; German data are for 1973:Q1-2008:Q2 (West Germany, 1973-1991); U.K. data are for 1958:Q1-2008:Q2. Numbers in parentheses represent $p$-values.

there is no universally agreed-upon theory as to why a relationship between the term spread and economic activity should exist. To a large extent, the usefulness of the spread for forecasting economic activity remains a "stylized fact in search of a theory" (Benati and Goodhart, 2008, p. 1237).

The expectations hypothesis of the term structure is the foundation of many explanations of the term spread's usefulness in forecasting output growth and recessions. The expectations hypothesis holds that long-term interest rates equal the sum of current and expected future short-term interest rates plus a term premium. The term premium explains why the yield curve usually slopes upward - that is, why the yields on longterm securities usually exceed those on short-term securities. However, the yield curve flattens or inverts-slopes downward-if the public expects short-term interest rates to fall. In that case, investors bid up the prices of longer-term securi- ties, which causes their yields to fall relative to current yields on short-term securities.

Many studies attribute the apparent ability of the term spread to forecast economic activity to actions by monetary authorities to stabilize output growth. For example, monetary policy tightening causes both short- and long-term interest rates to rise. Short-term rates are likely to rise more than long-term rates, however, if policy is expected to ease once economic activity slows or inflation declines. Hence, a policy tightening is likely to cause the yield curve to flatten or possibly invert. Monetary policy explanations usually have been stated with little underlying theory. ${ }^{4}$ However, as noted by Feroli (2004), Estrella (2005), and Estrella and Trubin (2006), the extent to which

4 For example, Estrella and Hardouvelis (1991) and Berk (1998) refer to simple dynamic IS-LM models but do not explicitly derive testable hypotheses from those models (see also Bernanke and Blinder, 1992; Dueker, 1997; and Dotsey, 1998). 
the term spread is a good predictor of output growth depends on the monetary authority's policy objectives and reaction function. For example, the term spread forecasts output growth better the more responsive the monetary authority is to deviations of output growth from potential. The spread forecasts less accurately if monetary authorities concentrate exclusively on controlling inflation. Further, changes in the relative responsiveness of the monetary authority to either output growth or inflation could cause changes in the ability of the term spread to forecast output growth.

In contrast to explanations that focus on monetary policy, theories of intertemporal consumption derive a relationship between the slope of the yield curve and future economic activity explicitly from the structure of the economy (e.g., Harvey, 1988; Hu, 1993). The central assumption of Harvey (1988), for example, is that individuals prefer stable consumption rather than high consumption during periods of rising income and low consumption when income is falling. Thus, when consumers expect a recession one year in the future, they will sell short-term financial instruments and purchase one-year discount bonds to obtain income during the recession year. As a result the term structure flattens or inverts. ${ }^{5}$

The theoretical implications of consumptionsmoothing models apply to the real term structure, that is, the term structure adjusted for expected inflation. However, much of the empirical evidence on the information content of the term structure pertains to the nominal term structure. The consistency of the empirical evidence linking the nominal yield curve to changes in output with the theoretical relationship depends on the persistence of inflation. If inflation were a random walk, implying that shocks to inflation are permanent, then inflation shocks would have no impact on the slope of the nominal yield curve because expected inflation would change by an identical amount at all horizons. However, if infla-

5 Rendu de Lint and Stolin (2003) study the relationship between the term structure and output growth in a dynamic equilibrium asset pricing model. They find that the term spread predicts future consumption and output growth at long horizons in a stochastic endowment economy model augmented with endogenous production. tion has little persistence, an inflation shock will affect near-term expected inflation more than longterm expected inflation, causing the slope of the nominal yield curve to change. Hence, the extent to which changes in the slope of the nominal yield curve reflect changes in the real yield curve depends on the persistence of inflation which, in turn, reflects the underlying monetary regime. ${ }^{6}$

Much of the empirical literature has focused on estimating the precision with which the term spread forecasts economic activity, rather than on attempting to discriminate between the monetary policy and consumption-smoothing explanations. Laurent $(1988,1989)$ argues that the yield curve reflects the stance of monetary policy and finds that the term spread predicts changes in the growth rate of real GDP. On the other hand, several studies find that the term spread has significant predictive power for economic growth independent of the information contained in measures of current and future monetary policy, suggesting that monetary policy alone cannot explain all of the observed relationship (see, e.g., Estrella and Hardouvelis, 1991; Plosser and Rouwenhorst, 1994; Estrella and Mishkin, 1997; Benati and Goodhart, 2008).

Harvey (1988) and Rendu de Lint and Stolin (2003) offer support for the consumptionsmoothing explanation by showing that the slope of the yield curve is useful for forecasting both consumption and output growth. Benati and Goodhart (2008), however, find that changes over time in the marginal predictive content of the nominal term spread for output growth do not match changes in inflation persistence, which they argue is evidence against the consumptionsmoothing explanation.

Several studies find that the spread has forecast output growth less accurately since the mid1980s, which some attribute to greater stability of output growth and other key macroeconomic data (e.g., D’Agostino, Giannone, and Surico, 2006). It remains to be seen how incorporating data for

\footnotetext{
6 Under fiat monetary regimes, inflation has tended to be highly persistent. However, inflation tends to exhibit little persistence under metallic and inflation-targeting regimes (see, e.g., Shiller and Siegel, 1977; Barsky, 1987; Bordo and Schwartz, 1999; and Benati, 2006, 2008).
} 
the recession that began in 2007 affects the performance of forecasting models that use the term spread to predict economic activity and whether the additional information sheds light on alternative explanations for the forecasting relationship.

\section{DOES THE TERM SPREAD FORECAST OUTPUT GROWTH?}

Numerous studies using a wide variety of data and methods investigate how well the term spread forecasts output growth. Although many studies use post-World War II U.S. data, several recent studies investigate how well the term spread predicts future economic activity using data from other countries or time periods. Such efforts can indicate whether the association between the term spread and output growth is an artifact of the postwar U.S. experience and shed light on the validity of alternative explanations for why the spread might forecast economic activity. Our survey focuses primarily on the literature published or written since the mid-1990s. However, we briefly discuss some earlier studies to set the stage for a more detailed discussion of recent work.

Much of the evidence on the accuracy of the term spread in forecasting output growth comes from the estimation of linear models, such as the following linear regression, or some variant of it:

$$
\Delta Y_{t}=\alpha+\beta \text { Spread }+\gamma(L) \Delta Y_{t-1}+\varepsilon_{t},
$$

where $\Delta Y_{t}$ is the growth rate of output (e.g., real GDP); Spread is the difference between the yields on long-term and short-term Treasury securities; $\gamma(L)$ is a lagged polynomial, typically of length four (current and three lags, assuming quarterly data); ${ }^{7}$ and $\varepsilon_{t}$ is an error term.

Laurent (1988), Harvey (1988, 1989), and Estrella and Hardouvelis (1991) were among the first to present empirical evidence on the strength of the relationship between the term spread and output growth using U.S. data. Harvey (1989), for example, finds that the spread between the yields on 5-year and 3-month U.S. Treasury securities predicts real gross national product growth from

\footnotetext{
${ }^{7}$ For example, $\gamma(L)=\gamma_{1} L^{1}+\gamma_{2} L^{2}+\gamma_{3} L^{3}+\gamma_{4} L^{4}$, where $L^{i} \Delta Y_{t}=\Delta Y_{t-i}$.
}

1 to 5 quarters ahead. Similarly, Estrella and Hardouvelis (1991) find that the spread between yields on 10-year and 3-month Treasury securities is useful for forecasting U.S. output growth and recessions, as well as consumption and investment, especially at 4- to 6-quarter horizons.

\section{Evidence from Outside the United States}

Although the earliest studies were based on U.S. data, several others have explored the usefulness of the spread for forecasting output growth using data from other countries. Often these studies show considerable variation across countries in how well the spread forecasts output growth. For example, Plosser and Rouwenhorst (1994) find that term spreads are useful for predicting GDP growth in Canada and Germany, as well as the United States, but not in France or the United Kingdom. Plosser and Rouwenhorst (1994) also find that foreign term spreads help predict future changes in output in individual countries.

Davis and Fagan (1997) find that the term spread has statistically significant within-sample explanatory power for output growth in six of nine European Union countries, but that the spread improves out-of-sample forecasts and satisfies conditions for statistical significance and stability in only three countries (Belgium, Denmark, and the United Kingdom). A related study by Berk and van Bergeijk (2001) examines 12 euro-area countries over the period 1970-98 and finds that the term spread contains only limited information about future output growth.

Several studies examine whether the term spread contains information about future output growth in Japan. Harvey (1991) finds that the spread contains no information about future economic activity in Japan for the period 1970-89. By contrast, $\mathrm{Hu}$ (1993) finds a positive correlation between the term spread and future economic activity in Japan for the period from January 1957 to April 1991, but that lagged changes in stock prices and output growth have more explanatory power than the term spread. Kim and Limpaphayom (1997) argue that heavy regulation prevented interest rates from reflecting market expectations before 1984. Their study finds that the spread is useful for predicting output growth up to five 
quarters ahead during 1984-91 (see also Nakaota, 2005).

\section{Evidence from Multivariate Models}

Several studies examine the marginal predictive content of the term spread in models that also include other explanatory variables. Estrella and Hardouvelis (1991), Plosser and Rouwenhorst (1994), Estrella and Mishkin (1997), Hamilton and Kim (2002), and Feroli (2004) are among several studies that find the term spread has significant predictive power for economic growth even when a short-term interest rate or other measure of the stance of monetary policy is included as an additional explanatory variable. These results suggest that monetary policy alone does not explain why the term spread predicts output growth. However, Stock and Watson (2003) show that including other explanatory variables does not improve forecasts obtained from a bivariate model of the term spread and output growth. ${ }^{8}$

Aretz and Peel (2008) include both the term spread and professional forecasts in a model of output growth and find that both variables individually forecast real GDP growth and that the term spread contains information not captured by professional forecasts. However, Aretz and Peel (2008) find that the term spread contributes no information beyond that in the professional forecasts in models that assume that forecasters' loss functions become more skewed as the forecast horizon lengthens.

Hamilton and Kim (2002) note that (i) the term spread consists of an expected interest rate component and a term premium component and (ii) determining the relative usefulness of one or the other component for forecasting output growth could help distinguish among alternative hypotheses for why the term spread predicts output growth. Hamilton and Kim (2002) find that the expected change in the short-term interest rate and the time-varying term premium both contribute to forecasts of real GDP growth up to eight

8 Similarly, Cozier and Tkacz (1994) and Hamilton and Kim (2002) find that the spread predicts future changes in output growth in forecasting models that include the output gap and changes in the price of oil, respectively, as an explanatory variable. quarters ahead. However, expected changes in short-term rates explain significantly more of the output growth than does the term premium. Hence, the most important reason that an inverted yield curve predicts slower output growth in the future is that a low term spread implies falling future short-term interest rates, rather than, say, an increase in the term premium associated with higher interest rate volatility near the end of economic expansions.

\section{Recent Research on the Stability of the Forecasting Relationship}

Table 2 summarizes the methods and principal findings of several recent studies of the ability of the term spread to forecast output growth. Much of the research during the past decade focuses on the stability of the forecasting relationship over time. Several studies find that the spread has been less useful for forecasting output growth since the mid-1980s, at least for the United States. ${ }^{9}$ For example, Dotsey (1998) finds that the spread forecasts cumulative output growth up to two years in the future, but does so less accurately for 1985-97 than for earlier years. Further, Dotsey (1998) finds that the spread forecasts less accurately when past values of output growth and short-term interest rates are included in the forecasting model and contributes no information to forecasts for the 1985-97 period.

Estrella, Rodrigues, and Schich (2003) test for unknown breakpoints in the in-sample forecasting relationship between the term spread and output growth using data for the United States and Germany. Although the study detects a generally strong relationship between the term spread and output growth one year in the future for both countries, it identifies a break in September 1983 for the United States using models with one-year forecast-horizons. Estrella, Rodrigues, and Schich (2003), however, detect no breaks in longer-horizon forecasting models for the United States or in short- or long-horizon models estimated using data for Germany.

\footnotetext{
9 In addition to the studies summarized in Table 2, other studies that find a break in the forecasting relationship in the mid-1980s include Haubrich and Dombrosky (1996), Estrella and Mishkin (1997), and Smets and Tsatsaronis (1997).
} 


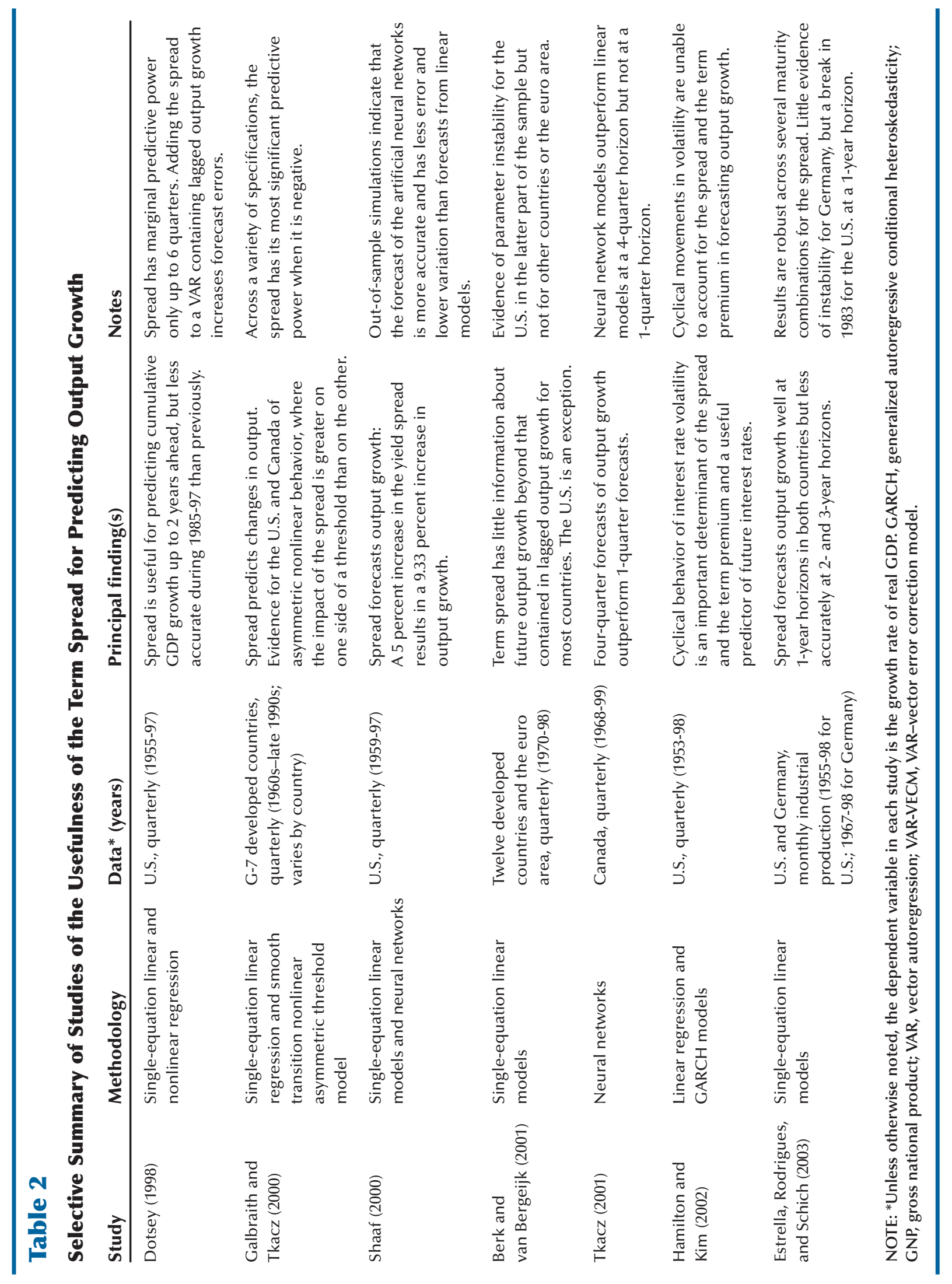




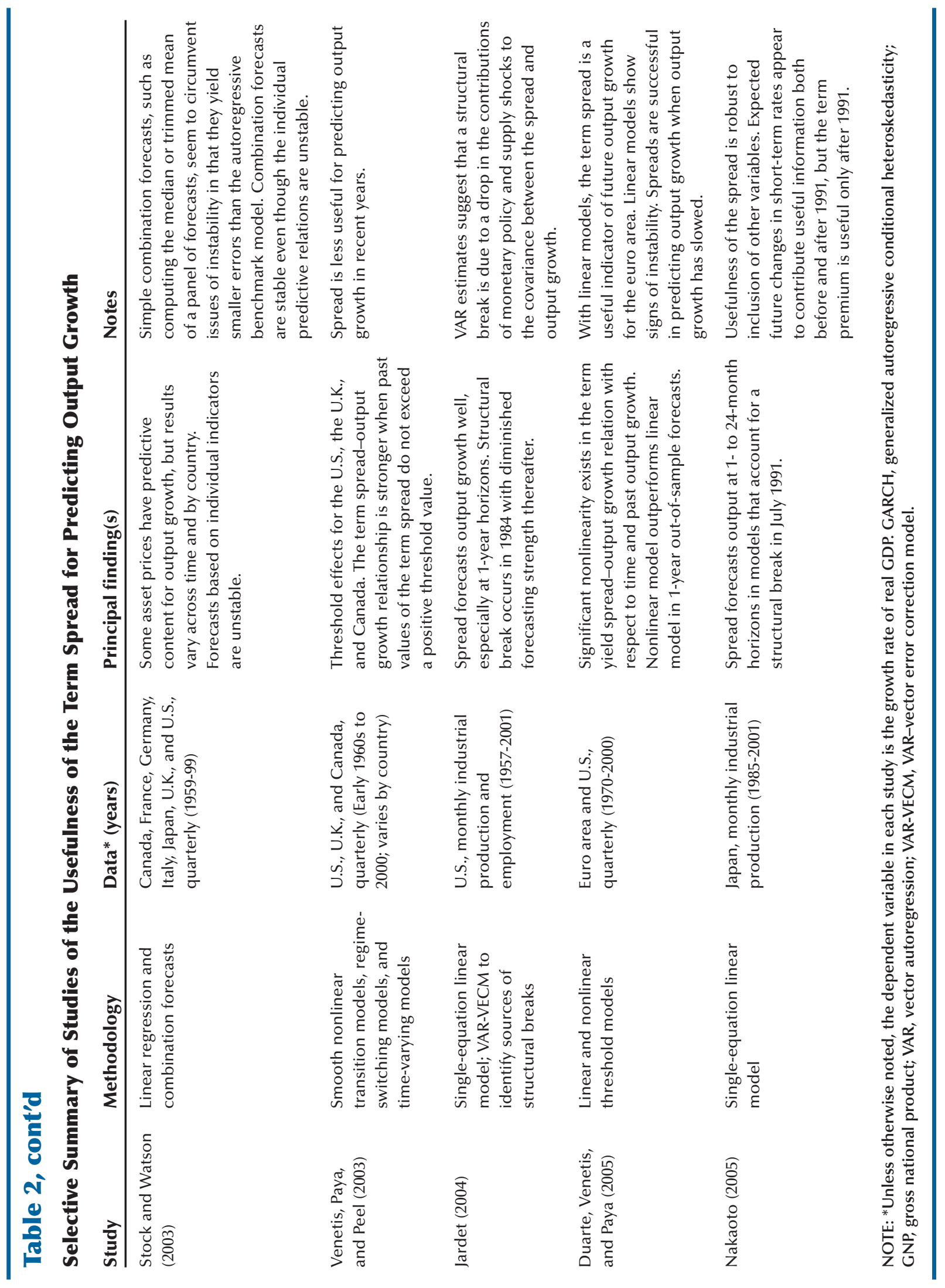




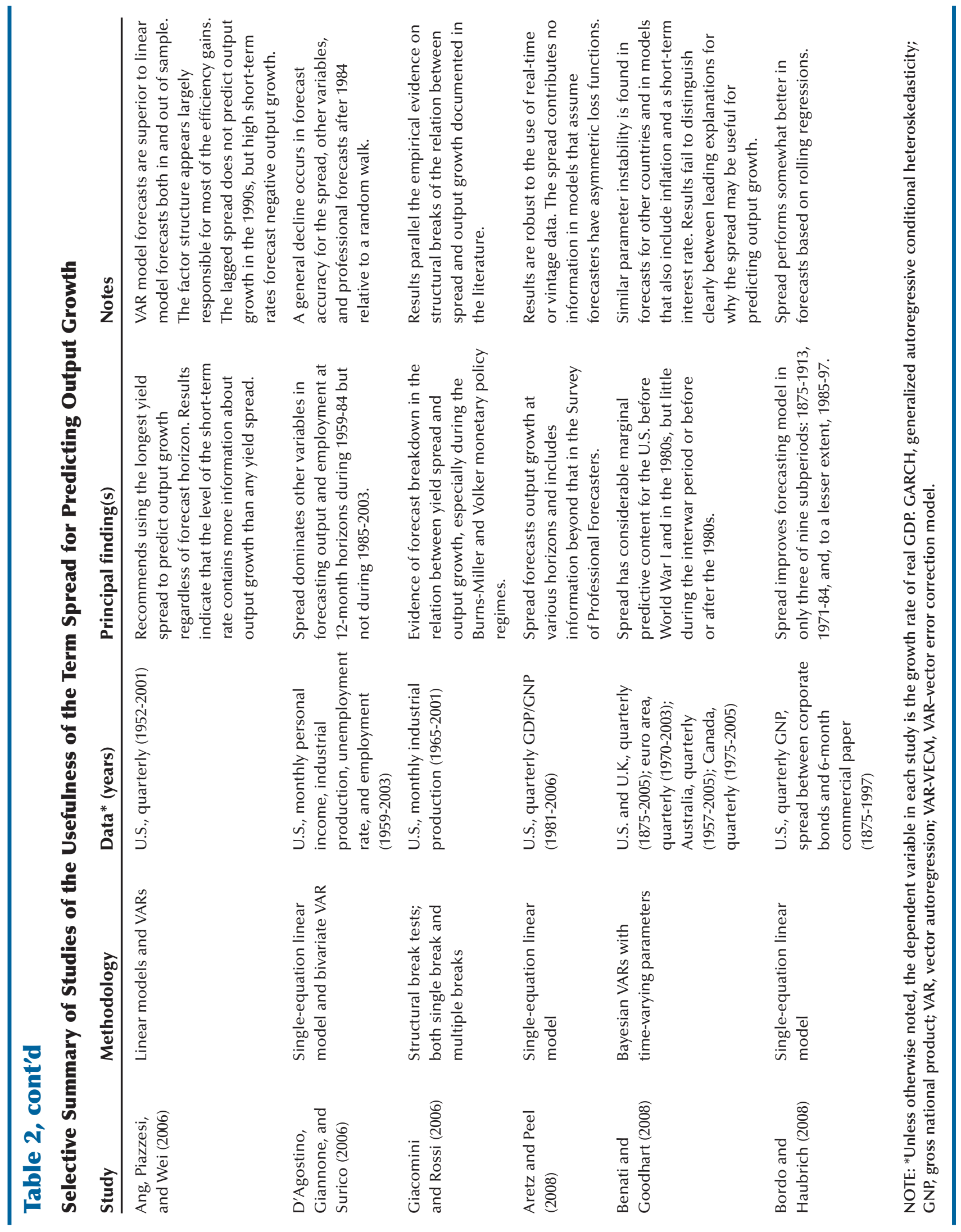


Stock and Watson (2003) examine the stability of the forecasting relationship between the term spread and output growth for the United States and other countries and consider both in-sample and out-of-sample forecasts. Like prior studies, Stock and Watson (2003) find that the term spread forecasts U.S. output growth less accurately after 1985. The study also finds that the spread forecasts output less accurately during 1985-99 than a simple autoregressive model.

A recent study by Giacomini and Rossi (2006) reexamines the forecasting performance of the yield curve for output growth using forecast breakdown tests developed by Giacomini and Rossi (2009). Giacomini and Rossi (2006) show that output growth models are characterized by a breakdown of predictability. In particular, they find strong evidence of forecast breakdowns at the one-year horizon during 1974-76 and 1979-87.

Several studies that find diminished performance of the term spread forecasts of output growth in recent years point to the increased stability of output growth and other macroeconomic variables since the mid-1980s (at least until 2007) as a possible reason for the apparent change. As noted previously, a change in the relative responsiveness of monetary policy to output growth and inflation could affect how well the term spread predicts output growth. Bordo and Haubrich $(2004,2008)$ investigate the ability of the term spread to forecast U.S. output growth across different monetary regimes from 1875 to 1997. The authors examine periods distinguished by major changes in the monetary and interest rate environment, including the founding of the Federal Reserve System in 1914, World War II, the Treasury-Fed Accord of 1951, and the closing of the U.S. gold window and collapse of the Bretton Woods system in 1971. Bordo and Haubrich $(2004,2008)$ find that the term spread improves the forecast of output growth, as indicated by the mean squared forecast error, in three of the nine subperiods they consider: (i) the period preceding the establishment of the Federal Reserve System (1875-1913), (ii) the first 13 years after the collapse of the Bretton Woods system (1971-84), and, to a lesser extent, (iii) the $1985-97$ period. ${ }^{10}$ The term spread does not improve forecasts of output growth during the interwar period or the Bretton Woods era that followed World War II.

Bordo and Haubrich $(2004,2008)$ find that the term spread tends to forecast output growth better during periods when the persistence of inflation was relatively high, such as the first 13 years after the collapse of the Bretton Woods system. In such periods, inflation shocks increase both short- and long-term interest rates and thus do not affect the slope of the yield curve. Real shocks that are expected to be temporary, however, increase short-term rates by more than long-term rates and signal a future downturn in economic activity. Bordo and Haubrich $(2004,2008)$ find that the term spread forecasts output growth less accurately when inflation persistence is relatively low, as it was during the interwar period and the Bretton Woods era. In such periods, both inflation and real shocks increase short-term interest rates more than long-term rates. Bordo and Haubrich argue, however, that only real shocks are likely to affect future output growth and, hence, the lower the persistence of inflation, the noisier the signal produced by the term spread about future output growth.

Benati and Goodhart (2008) extend the work of Bordo and Haubrich $(2004,2008)$ by (i) considering the marginal predictive content of the term spread for forecasting output growth in a multivariate model and (ii) attempting to date more precisely changes in the marginal predictive content of the spread over time. Whereas Bordo and Haubrich $(2004,2008)$ estimate bivariate regression models similar to equation (1), Benati and Goodhart (2008) estimate Bayesian time-varying parameter vector autoregressions (VARs).

Benati and Goodhart (2008) find that the term spread forecasts U.S. output growth better during the 1880s and 1890s than during the first two decades of the twentieth century. Further, like Bordo and Haubrich (2004, 2008), Benati and Goodhart (2008) find that the spread has almost no predictive content for the interwar years or the

\footnotetext{
${ }^{10}$ Bordo and Haubrich $(2004,2008)$ also estimate rolling regressions with 24-quarter windows and find that the term spread predicts output less accurately during the pre-Fed period than suggested by their original estimates. However, their results for the post-Bretton Woods era are robust to the use of rolling regressions.
} 
Bretton Woods era. In addition, the study finds that the term spread contains significant predictive information about output growth during 1979-87 but none for other postwar years. Benati and Goodhart (2008) also find that estimates of the marginal predictive content of the spread are sensitive to whether a short-term interest rate and inflation are included in the forecasting model, and they find considerable variation in the marginal predictive content of the term spread over time for other countries and for different forecast horizons. Thus, like Bordo and Haubrich (2004, 2008), Benati and Goodhart (2008) find numerous breaks in the relationship between the term spread and future changes in output over time. However, unlike Bordo and Haubrich $(2004,2008)$, the breaks identified by Benati and Goodhart (2008) are not clearly associated with changes in the monetary regime or inflation persistence.

\section{Evidence from Nonlinear Models}

Much of the literature investigating the performance of the term spread in forecasting output growth relies on linear models. However, variation over time in the ability of the term spread to forecast output growth suggests possible nonlinearities in the forecasting relationship and some recent studies using data for the United States and Canada find this to be the case. Further, researchers are beginning to use models that capture such nonlinearities. For example, Galbraith and Tkacz (2000) find evidence of a threshold effect in the relationship between the term spread and conditional expectations of output growth for the United States and Canada but not for other major developed countries. Specifically, the authors find a large and statistically significant impact of the term spread on conditional expectations of output growth. However, the marginal effect that an increase in the spread has on predicted output growth is lower when the level of the term spread rises above a certain point.

Shaaf (2000) and Tkacz (2001) use neural network models to account for nonlinearity in the relationship between the term spread and output growth. Both studies find that this class of models produces smaller forecast errors than linear models. Venetis, Paya, and Peel (2003) use non- linear smooth transition models that can accommodate regime-type nonlinear behavior and time-varying parameters to examine the predictive power and stability of the term spread-output growth relationship. Using data for the United States, United Kingdom, and Canada, Venetis, Paya, and Peel (2003) find that the term spreadoutput growth relationship is stronger when past values of the term spread do not exceed a positive threshold value. ${ }^{11}$

Duarte, Venetis, and Paya (2005) use both linear regression and nonlinear models to examine the predictive accuracy of the term spreadoutput growth relationship among euro-area countries. The authors find that linear indicator and nonlinear threshold indicator models predict output growth well at four-quarter horizons and that the term spread is a useful indicator of future output growth and recessions in the euro area. The linear models show signs of instability, however, and the authors find evidence of significant nonlinearities with respect to time and lagged output growth. Further, the authors' nonlinear model outperforms their linear model in out-ofsample forecasts of one-year-ahead output growth.

Ang, Piazzesi, and Wei (2006) point out that the regressions typically used to investigate the predictive content of the term spread are unconstrained, and the authors argue for a model that treats both the term spread and output growth as endogenous variables. Ang, Piazzesi, and Wei (2006) build a dynamic model of GDP growth and bond yields that completely characterizes expectations of GDP growth. Using quarterly U.S. data for 1952-2001, the authors find that, contrary to previous research, the short-term interest rate outperforms the term spread in forecasting real GDP growth both in and out of sample and that including the term spread does not significantly improve forecasts of output growth.

In summary, the recent empirical literature on the usefulness of the term spread for forecasting output growth finds that the spread predicts output growth less accurately in some countries and some periods than in others. Notably, several

\footnotetext{
${ }^{11}$ For a discussion of smooth transition regression, see Granger and Teräsvirta (1993) or Teräsvirta (1998).
} 
studies find that the term spread's power to forecast output has diminished since the mid-1980s. Several recent studies find evidence of significant nonlinearities, such as threshold effects, in the empirical relationship between the term spread and output growth.

\section{DOES THE TERM SPREAD FORECAST RECESSIONS?}

As an alternative to using the term spread to forecast output growth, many studies examine the extent to which the term spread is useful for forecasting the onset of recessions. Several of those studies are summarized in Table 3.

Most recession-forecasting studies estimate a probit model of the following type, in which the dependent variable is a categorical variable set equal to 1 for recession periods and to 0 otherwise:

$$
P\left(\text { recession }_{t}\right)=F\left(\alpha_{0}+\alpha_{1} S_{t-k}\right),
$$

where $F$ indicates the cumulative normal distribution function. If the coefficient $\alpha_{1}$ is statistically significant, then the term spread, $S_{t-k}$, is deemed useful for forecasting a recession $k$ periods ahead.

Models of the following form are often used to test how well the spread predicts recessions when additional explanatory variables are included in the model:

$$
P\left(\text { recession }_{t}\right)=F\left(\alpha_{0}+\alpha_{1} S_{t-k}+\alpha_{2} X_{t-k}\right),
$$

where $X_{t-k}$ is a vector of additional explanatory variables. If $\alpha_{1}$ is significant in equation (2) but not in equation (3), then the ability of the spread to predict recessions is not robust to the inclusion of other variables.

Using probit estimation, Estrella and Hardouvelis (1991) and Estrella and Mishkin (1998) find that the term spread significantly outperforms other financial and macroeconomic variables in forecasting U.S. recessions. Estrella and Hardouvelis (1991) show that the spread between the yields on 10-year and 3-month Treasury securities is a useful predictor of recessions, as well as of future growth of output, consumption, and investment. Estrella and Mishkin
(1998) compare the ability of several financial variables, including interest rates, interest rate spreads, stock prices, and monetary aggregates, to predict U.S. recessions out of sample. They find that stock prices are useful for predicting recessions at one- to three-quarter horizons but that the term spread outperforms all other variables beyond a one-quarter forecast horizon. Moreover, based on U.S. data for 1955-98 and German data for 1967-98, Estrella, Rodrigues, and Schich (2003) find that models that use the term spread to predict recessions are more stable than forecasting models for continuous variables, such as GDP growth and industrial production.

The term spread appears useful for predicting recessions in many countries. Using probit estimation, Bernard and Gerlach (1998) find that the term spread forecasts recessions up to two years ahead in eight countries (Belgium, Canada, France, Germany, Japan, the Netherlands, United Kingdom, and United States) over the 1972-93 period. Similarly, Moneta (2005) finds that the spread is useful for predicting recession probabilities for the euro area as a whole, as well as in individual countries. ${ }^{12}$

Several studies test whether the term spread remains useful for predicting recessions in multivariate forecasting models. For example, Dueker's (1997) probit model includes the change in an index of leading economic indicators, real money stock growth, the spread between the 6-month commercial paper and Treasury bill rates, and the percentage change in a stock price index, as well as the difference in yields on 30-year Treasury bonds and 3-month Treasury bills as a measure of the term spread. Dueker (1997) finds that among the variables, the term spread is the dominant predictor of recessions at horizons beyond three months.

Bernard and Gerlach (1998) include both an index of leading indicators and foreign interest rate term spreads in a recession-forecasting model. The index of leading indicators contains information beyond that in the term spreads, but the

\footnotetext{
12 Moneta (2005) examines the predictive power of 10 yield spreads, representing different segments of the yield curve, and finds that the spread between the yield on 10-year government bonds and the 3-month interbank rate outperforms all other spreads in predicting recessions in the euro area.
} 
information is useful only for forecasting recessions in the immediate future. Bernard and Gerlach (1998) find that in addition to the domestic term spread, the term spreads of Germany and the United States are particularly useful for forecasting recessions in Japan and the United Kingdom, respectively.

Sensier et al. (2004) use logit models to predict recessions in four European countries. The authors find that international data (in particular, the U.S. index of leading indicators and short-term interest rate) are useful for predicting business cycles in the four countries. The domestic term spread helps forecast recessions in Germany when international variables are included in the model, and short- and long-term interest rates entered separately help forecast recessions in France and the United Kingdom.

Wright (2006) confirms previous studies in finding that the term spread is highly statistically significant in a bivariate probit recession model estimated on U.S. data for 1964-2005. However, Wright (2006) also finds that a model that includes both the federal funds rate and term spread fits the data much better than the bivariate model and provides superior out-of-sample recession forecasts. Similarly, King, Levin, and Perli (2007) find that a model that includes a corporate credit spread produces superior in- and out-of-sample recession forecasts compared with a model that includes only the term spread. In addition, they find that the multivariate model produces a much lower incidence of false-positive recession predictions.

Rosenberg and Maurer (2008) investigate whether recession forecasts can be improved by distinguishing between the interest rate expectations and term premium components of the term spread. Their approach is similar to that of Hamilton and Kim (2002) discussed previously. If changes in the term premium distort the empirical relationship between the spread and recessions, a model that isolates interest rate expectations might yield superior recession forecasts. Rosenberg and Maurer (2008) find that the expectations component is more useful for forecasting recessions than the term premium and that only the coefficient on the expectations component is statistically significant in the probit model. Their study finds, however, that the term spread and expectations component generally produce similar recession probability forecasts. Moreover, between August 2006 and May 2007, the term spread model predicted a significantly higher recession probability than did the expectations component model.

Several recent studies investigate nonlinearities in recession-forecasting models. For example, Dueker (1997) estimates a probit model with Markov-switching coefficient variation and a lagged dependent variable. He finds that allowing for Markov-switching coefficient variation on the term spread improves forecast accuracy, especially at longer horizons, while including the lagged value of the recession indicator improves the model's fit and forecast accuracy, especially at 3- to 12-month horizons. Further, Dueker (1997) finds that the nonlinear model produces fewer false warnings of recessions than a linear model.

Ahrens (2002) estimates a probit forecasting model in which the term spread is assumed to follow a two-state Markov process. Using data for 1970-96 for eight countries among the Organisation for Economic Co-operation and Development (Canada, France, Germany, Italy, Japan, the Netherlands, the United Kingdom, and the United States), Ahrens (2002) finds that the term spread is a reliable predictor of business cycle peaks and troughs. Like Dueker (1997), Ahrens (2002) finds that the regime-switching framework produces more-accurate estimates of recession probabilities.

Other studies that estimate augmented probit (or logit) models, or compare results from probit estimation with those obtained using other methods, include Chauvet and Potter (2005), Galvao (2006), and Dueker (2005).

Chauvet and Potter (2005) compare recession forecasts obtained using four different probit model specifications: (i) a time-invariant conditionally independent version, (ii) a business cycle-specific conditionally independent model, (iii) a time-invariant probit model with autocorrelated errors, and (iv) a business cycle-specific probit model with autocorrelated errors. Chauvet and Potter (2005) find evidence in favor of the 


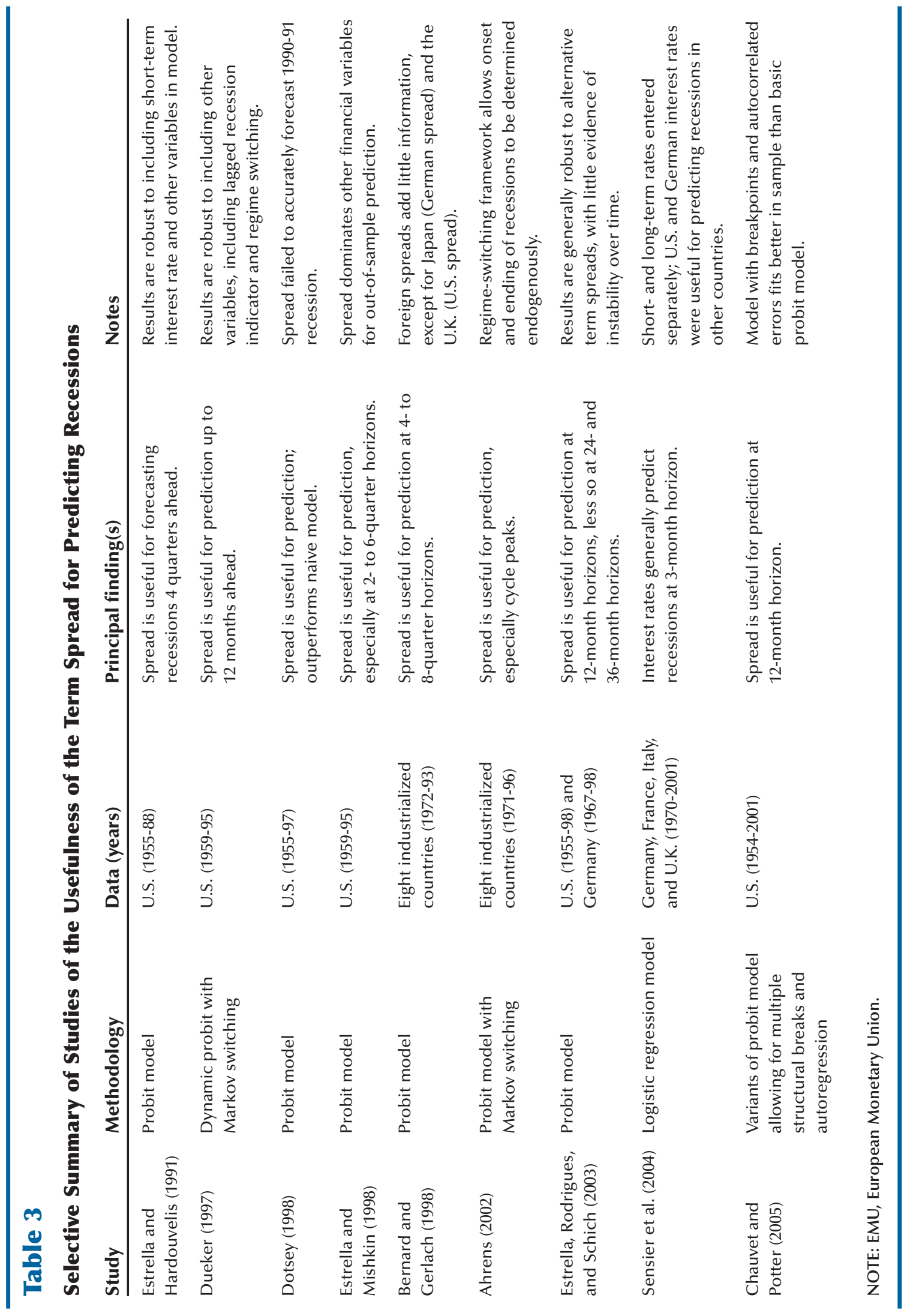




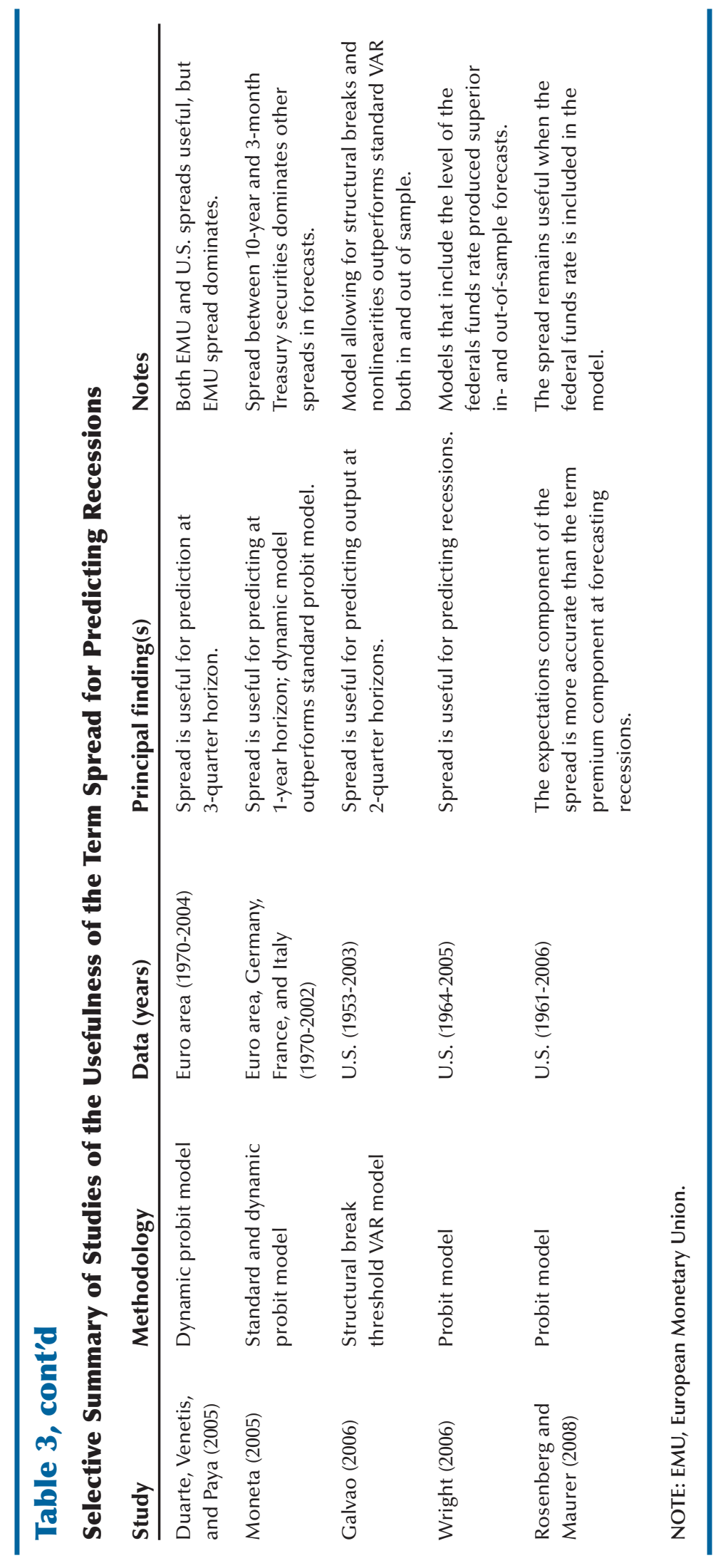


business cycle-specific probit model with autocorrelated errors, which allows for multiple structural breaks across business cycles and autocorrelation.

Galvao (2006) estimates a recession-forecasting model that accounts for time-varying nonlinearity and structural breaks in the relationship between the term spread and recessions. The author finds that a model with time-varying thresholds predicts the timing of recessions better than models with a constant threshold or that allow only a structural break.

Finally, Dueker (2005) proposes a VAR (“Qual-VAR”) model to forecast recessions using data on the term spread, GDP growth, inflation, and the federal funds rate. He finds that the model fits well in sample and accurately forecasts the 2001 recession out of sample.

In summary, most empirical research to date finds that the term spread is useful for forecasting recessions-both for the United States and other countries-and that the spread predicts recessions more reliably than it does output growth. However, a few studies find that multivariate models that include other financial indicators besides the term spread improve recession-forecasting performance, as do models that account for threshold effects or other nonlinearities in the empirical relationship between the term spread and recessions.

\section{CONCLUSION}

The literature on the relationship between the yield curve and economic activity is large and expanding rapidly. Much of the literature examines empirically how well the term spread forecasts output growth or recessions, with less emphasis on why the yield curve predicts economic activity. To a great extent, the observation that changes in the slope of the yield curve appear to forecast changes in economic activity remains, as Benati and Goodhart (2008, p. 1237) contend, "a stylized fact in search of a theory."

Does the yield spread forecast output growth? Does it forecast recessions? The answer to both questions is a qualified "yes." Early studies based on estimation of linear forecasting models using postwar U.S. data, as well as several recent studies, find that the term spread forecasts output growth well. Much research finds that the term spread is useful for forecasting output growth, especially at horizons of 6 to 12 months, and that the term spread remains useful even if other variables, including measures of monetary policy, are added to the forecasting model. However, several recent studies also find considerable variation in the ability of the spread to forecast output growth across countries and time periods. In particular, several studies find that the spread's ability to predict output growth has diminished since the mid-1980s. The literature also provides considerable evidence of nonlinearities and structural breaks in the relationship between the term spread and output growth.

In general, studies show that the term spread is a more reliable predictor of recessions than of output growth and that the spread provides good recession forecasts, especially up to one year ahead. Researchers generally obtain superior forecasting performance from (i) probit models that include a lagged recession indicator and Markovswitching coefficients or other nonlinearities and (ii) other nonlinear approaches, such as smooth transition regression and multivariate adaptive regression splines estimation.

The literature has not reached a consensus regarding the reasons for structural breaks or nonlinearities in the empirical relationship between the term spread and future economic activity. Several studies note that the relationship between the nominal yield curve and future economic activity is likely to depend on the nature of the monetary regime, including the relative responsiveness of the monetary authority to output and inflation. For example, the term spread is likely to forecast output growth better when the monetary authority is more responsive to output than inflation and when inflation is relatively persistent. Further estimation refinements, as well as additional research based on dynamic structural models (Ang, Piazzesi, and Wei, 2006), might provide insights into the interactions among the policy regime, financial variables, and output growth that help explain the questions posed by the empirical literature. 


\section{REFERENCES}

Ahrens, Ralf. "Predicting Recessions with Interest Rate Spreads: A Multicountry Regime-Switching Analysis." Journal of International Money and Finance, August 2002, 21(4), pp. 519-37.

Ang, Andrew; Piazzesi, Monika and Wei, Min. "What Does the Yield Curve Tell Us About GDP Growth?" Journal of Econometrics, March/April 2006, 131(1/2), pp. 359-403.

Aretz, Kevin and Peel, David A. "Spreads versus Professional Forecasters as Predictors of Future Output Change.” Working paper, Lancaster University, 2008; http://ssrn.com/abstract=1123949.

Barsky, Robert B. "The Fisher Hypothesis and the Forecastability and Persistence of Inflation.” Journal of Monetary Economics, January 1987, 19(1), pp. 3-24.

Benati, Luca. "UK Monetary Regimes and Macroeconomic Stylized Facts.” Bank of England Working Paper 290, Bank of England, March 2006; www.bankofengland.co.uk/publications/ workingpapers/wp290.pdf.

Benati, Luca. "Investigating Inflation Persistence Across Monetary Regimes,” Quarterly Journal of Economics, August 2008, 123(3), pp. 1005-60.

Benati, Luca and Goodhart, Charles. "Investigating Time-Variation in the Marginal Predictive Power of the Yield Spread." Journal of Economic Dynamics and Control, April 2008, 32(4), pp. 1236-72.

Berk, Jan M. "The Information Content of the Yield Curve for Monetary Policy: A Survey." De Economist, July 1998, 146(2), pp. 303-20.

Berk, Jan M. and van Bergeijk, Peter A.G. "On the Information Content of the Yield Curve: Lessons for the Eurosystem?" Kredit und Kapital, 2001, 1, pp. 28-47.

Bernanke, Ben S. and Blinder, Alan S. "The Federal Funds Rate and the Channels of Monetary Transmission." American Economic Review, September 1992, 82(4), pp. 901-21.

Bernard, Henri and Gerlach, Stefan. "Does the Term
Structure Predict Recessions? The International Evidence." International Journal of Finance and Economics, July 1998, 3(3), pp. 195-215.

Bordo, Michael D. and Haubrich, Joseph G. "The Yield Curve, Recessions, and the Credibility of the Monetary Regime: Long-Run Evidence, 1875-1997.” NBER Working Paper No. 10431, National Bureau of Economic Research, April 2004;

www.nber.org/papers/w10431.pdf?new_window=1.

Bordo, Michael D. and Haubrich, Joseph G. "The Yield Curve as a Predictor of Growth: Long-run Evidence, 1875-1997." Review of Economics and Statistics, February 2008, 90(1), pp. 182-85.

Bordo, Michael D. and Schwartz, Anna J. "Monetary Policy Regimes and Economic Performance: The Historical Record," in John B. Taylor and Michael Woodford, eds., Handbook of Macroeconomics. Chap. 2. Amsterdam: North Holland, 1999.

Chauvet, Marcelle and Potter, Simon. "Forecasting Recessions Using the Yield Curve.” Journal of Forecasting, March 2005, 24(2), pp. 77-103.

Cozier, Barry and Tkacz, Greg. "The Term Structure and Real Activity in Canada." Bank of Canada Working Paper No. 94-3, Bank of Canada, March 1994; www.bankofcanada.ca/en/res/wp/1994/wp94-3.pdf.

D’Agostino, Antonello; Domenico, Giannone and Surico, Paolo. "(Un)predictability and Macroeconomic Stability.” European Central Bank Working Paper No. 605, European Central Bank, April 2006; www.ecb.int/pub/pdf/scpwps/ecbwp605.pdf.

Davis, E. Phillip and Fagan, Gabriel. "Are Financial Spreads Useful Indicators of Future Inflation and Output Growth in EU Countries?" Journal of Applied Econometrics, November/December 1997, 12(6), pp. 701-14.

Dotsey, Michael. "The Predictive Content of the Interest Rate Yield Spread for Future Economic Growth.” Federal Reserve Bank of Richmond Economic Quarterly, Summer 1998, 84(3), pp. 31-51; www.richmondfed.org/publications/research/ economic_quarterly/1998/summer/pdf/dotsey.pdf. 
Duarte, Augustin; Venetis, Ioannis A. and Paya, Ivan. "Predicting Real Growth and the Probability of Recession in the Euro Area Using the Yield Spread." International Journal of Forecasting, April/June 2005, 21(2), pp. 262-77.

Dueker, Michael J. "Strengthening the Case for the Yield Curve as a Predictor of U.S. Recessions.” Federal Reserve Bank of St. Louis Review, March/April 1997, 79(2), pp. 41-51; http://research.stlouisfed.org/ publications/review/97/03/9703md.pdf.

Dueker, Michael J. "Dynamic Forecasts of Qualitative Variables: A Qual VAR Model of U.S. Recessions." Journal of Business and Economics Statistics, January 2005, 23(1), pp. 96-104.

Estrella, Arturo. "Why Does the Yield Curve Predict Output and Inflation?" Economic Journal, July 2005, 115(505), pp. 722-44.

Estrella, Arturo and Hardouvelis, Gikas A. "The Term Structure as a Predictor of Real Economic Activity." Journal of Finance, June 1991, 46(2), pp. 555-76.

Estrella, Arturo and Mishkin, Frederic S. "The Predictive Power of the Term Structure of Interest Rates in Europe and the United States: Implications for the European Central Bank." European Economic Review, July 1997, 41(7), pp. 1375-401.

Estrella, Arturo and Mishkin, Frederic S. "Predicting U.S. Recessions: Financial Variables as Leading Indicators." Review of Economics and Statistics, February 1998, 80(1), pp. 45-61.

Estrella, Arturo; Rodrigues, Anthony P. and Schich, Sebastian. "How Stable Is the Predictive Power of the Yield Curve? Evidence from Germany and the United States." Review of Economics and Statistics, August 2003, 85(3), pp. 629-44.

Estrella, Arturo and Trubin, Mary R. "The Yield Curve as a Leading Indicator: Some Practical Issues.” Federal Reserve Bank of New York Current Issues in Economics and Finance, July/August 2006, 12(5), pp. 1-7; www.newyorkfed.org/research/ current_issues/ci12-5.pdf.
Feroli, Michael. "Monetary Policy and the Information Content of the Yield Spread." Topics in Macroeconomics, September 2004, 4(1), Article 13.

Galbraith, John W. and Tkacz, Greg. "Testing for Asymmetry in the Link Between the Yield Spread and Output in the G-7 Countries." Journal of International Money and Finance, October 2000, 19(5), pp. 657-72.

Galvão, Ana Beatriz C. "Structural Break Threshold VARs for Predicting U.S. Recessions Using the Spread." Journal of Applied Econometrics, May/June 2006, 21(4), pp. 463-87.

Giacomini, Raffaella and Rossi, Barbara. "How Stable Is the Forecasting Performance of the Yield Curve for Output Growth?" Oxford Bulletin of Economics and Statistics, December 2006, 68(Suppl. 1), pp. 783-95.

Giacomini, Raffaela and Rossi, Barbara. "Detecting and Predicting Forecast Breakdown." Review of Economic Studies, April 2009, 76(2), pp. 669-705.

Granger, Clyde W. J. and Teräsvirta, Timo. Modeling Nonlinear Economic Relationships. New York: Oxford University Press, 1993.

Hamilton, James D. and Kim, Dong H. "A ReExamination of the Predictability of the Yield Spread for Real Economic Activity." Journal of Money, Credit, and Banking, May 2002, 34(2), pp. 340-60.

Harvey, Campbell R. "The Real Term Structure and Consumption Growth," Journal of Financial Economics, December 1988, 22(2), pp. 305-33.

Harvey, Campbell R. "Forecasts of Economic Growth From the Bond and Stock Markets." Financial Analysts Journal, September/October 1989, 45(5), pp. 38-45.

Harvey, Campbell R. "The Term Structure and World Economic Growth." Journal of Fixed Income, June 1991, 1(1), pp. 7-19.

Haubrich, Joseph G. and Dombrosky, Ann M. "Predicting Real Growth Using the Yield Curve." 
Federal Reserve Bank of Cleveland Economic Review, First Quarter 1996, 32(1), pp. 26-35; www.clevelandfed.org/Research/Review/1996/ 96-q1-haubrich.pdf.

$\mathrm{Hu}$, Zuliu. "The Yield Curve and Real Economic Activity." IMF Staff Papers, December 1993, 40(4), pp. 781-806.

Jardet, Caroline. "Why Did the Term Structure of Interest Rates Lose Its Predictive Power?" Economic Modelling, May 2004, 21(3), pp. 509-24.

Kessel, Reuben, A. "The Cyclical Behavior of the Term Structure of Interest Rates.” NBER Occasional Paper 91, National Bureau of Economic Research, 1965.

Kim, Kenneth A. and Limpaphayom, Piman. "The Effect of Economic Regimes on the Relation Between Term Structure and Real Activity in Japan." Journal of Economics and Business, July/August 1997, 49(4), pp. 379-92.

King, Thomas B.; Levin, Andrew T. and Perli, Roberto. "Financial Market Perceptions of Recession Risk." Finance and Economics Discussion Series No. 2007-57, Board of Governors of the Federal Reserve System; www.federalreserve.gov/pubs/feds/2007/ 200757/index.html.

Laurent, Robert D. "An Interest Rate-Based Indicator of Monetary Policy.” Federal Reserve Bank of Chicago Economic Perspectives, 1988, 12(1), pp. 3-14; www.chicagofed.org/publications/ economicperspectives/1988/ep_jan_feb1988_part1_ laurent.pdf.

Laurent, Robert D. "Testing the 'Spread.”' Federal Reserve Bank of Chicago Economic Perspectives, 1989, 13(4), pp. 22-34; www.chicagofed.org/ publications/economicperspectives/1989/ep_jul_ aug1989_part3_laurent.pdf.

Moneta, F. "Does the Yield Spread Predict Recession in the Euro Area?" International Finance, Summer 2005, 8(2), pp. 263-301.

Nakaota, Hiroshi. "The Term Structure of Interest Rates in Japan: The Predictability of Economic
Activity." Japan and the World Economy, August 2005, 17(3), pp. 311-26.

Plosser, Charles I. and Rouwenhorst, K. Geert. "International Term Structures and Real Economic Growth." Journal of Monetary Economics, February 1994, 33(1), pp. 133-55.

Rendu de Lint, Christel and Stolin, David. "The Predictive Power of the Yield Curve: A Theoretical Assessment." Journal of Monetary Economics, October 2003, 50(7), pp. 1603-22.

Rosenberg, Joshua V. and Maurer, Samuel. "Signal or Noise? Implications of the Term Premium for Recession Forecasting." Federal Reserve Bank of New York Economic Policy Review, July 2008, 14(1), pp. 1-11; www.newyorkfed.org/research/epr/ 08v14n1/0807rose.pdf.

Sensier, Marianne; Artis, Michael J.; Osborn, Denise R. and Birchenhall, Chris. "Domestic and International Influences on Business Cycle Regimes in Europe." International Journal of Forecasting, April/June 2004, 20(2), pp. 343-57.

Shaaf, Mohamad. "Predicting Recessions Using the Yield Curve: An Artificial Intelligence and Econometric Comparison.” Eastern Economic Journal, Spring 2000, 26(2), pp. 171-90.

Shiller, Robert J. and Siegel, Jeremy J. "The Gibson Paradox and Historical Movements in Real Longterm Interest Rates." Journal of Political Economy, October 1977, 85(1), pp. 11-30.

Smets, Frank and Tsatsaronis, Kostas. "Why Does the Yield Curve Predict Economic Activity? Dissecting the Evidence for Germany and the United States." CEPR Discussion Paper No. 1758, Centre for Economic Policy Research, December 1997.

Stock, James H. and Watson, Mark W. "Forecasting Output and Inflation: The Role of Asset Prices." Journal of Economic Literature, September 2003, 41(3), pp. 788-829.

Teräsvirta, Timo. "Modeling Economic Relationships with Smooth Transition Regressions," in Aman Ullah and David E.A. Giles, eds., Handbook of 


\section{Wheelock and Wohar}

Applied Economic Statistics. Chap. 15. New York: Marcel Dekker, 1998, pp. 507-32.

Tkacz, Greg. "Neural Network Forecasting of Canadian GDP Growth." International Journal of

Forecasting, January/March 2001, 17(1), pp. 57-69.

Venetis, Ioannis A.; Paya, Ivan and Peel, David A. "Re-Examination of the Predictability of Economic Activity Using the Yield Spread: A Nonlinear Approach." International Review of Economics and Finance, 2003, 12(2), pp. 187-207.

Wright, Jonathan, H. "The Yield Curve and Predicting Recessions." Finance and Economics Discussion Series No. 2006-07, Federal Reserve Board of Governors, February 2006; www.federalreserve.gov/ pubs/feds/2006/200607/200607pap.pdf. 